\title{
Claudia Olk
}

\section{Configurations of Jewishness in Modernism: Woolf and Joyce}

In May 1935, Virginia and Leonard Woolf drove from London via the Netherlands and Germany to take a vacation in Italy. In the car with them was their little pet marmoset by the name of Mitzi. At the Dutch border to Germany, as Virginia Woolf notes in her diary, they felt enormous relief, when the German custom officers let them pass and when "the officers smile[d] at Mitzi" (Woolf 1982, 311). She then describes the scene in which they, on their way to a hotel on the Rhein near Bonn, were inadvertently driven through a welcome reception arranged for the Minister President Goering: "We were chased across the river by Hitler (or Goering) had to pass through ranks of children with red flags. They cheered Mitzi. I raised my hand. People gathering in the sunshine - rather forced like school sports. Banners stretched across the street 'The Jew is our enemy' [...] Our obsequiousness gradually turning to anger” (Woolf 1982, 311).

This bizarre but dangerous first-hand experience for the accomplished writer and her Jewish husband, in which the couple was perhaps saved by their exotic pet, further increased Woolf's disdain of fascism, war and imperialism that she poignantly combines with her feminist stance in works like Three Guineas (1938) in the form of three imaginary letters to a poet.

Yet, Virginia Woolf's works, as many critics have noted, present an ambivalent example, when it comes to representations of Jewishness. In her novels and stories, Jewish stereotyping occurs frequently, but so do her increasing attacks on fascism in the 1930s (Simpson 2016, 32). Early on, both Leonard and Virginia Woolf were acutely aware of the dangers of rising fascism in Europe. They looked to Germany, Spain and Italy with concern but were also alarmed by the activities of Oswald Mosley's “British Union of Fascists” that had gained much popularity in the mid-1930s and in 1934 ironically set up its headquarters at Hogarth House, Richmond, which had been Virginia and Leonard Woolf's residence from 1915 to 1924. In 1935, Leonard Woolf remembers "people were just beginning to understand" the menace that Hitler and the Nazis presented (L. Woolf 1967, 192). He also recalls feeling shocked and helpless to see how "a powerful nation completely subservient to a gang of squalid, murderous hooligans" destroyed civilisation (L. Woolf 1967, 248).

The Woolfs were at the centre of many modernist literary circles. Both Leonard and Virginia were part of the Bloomsbury Group, both actively engaged in journalism and literary criticism and both established their own Publishing 
House, The Hogarth Press, in 1917 which became an important agent in the dissemination of Jewish literature. Woolf had met Sigmund Freud, who after his emigration was living in Hampstead with his daughter Anna Freud, and the Press published the Standard Edition of his Complete Psychological Works in James Strachey's translation. The Press also contracted and printed the only novel The Refugees (1938) by Jewish American author Libby Benedict, which is set in Berlin, Paris and London after the Reichstagsbrand in 1933 and records the fate of several people who chose to stay in Germany or decided to leave (Gillespie 2016, 18).

In the same year, the Hogarth Press published Woolf's Three Guineas in which she famously describes herself as an outsider: "as a woman, I have no country. As a woman I want no country. As a woman my country is the whole world" (Woolf 2001, 99). With the Second World War entering into more devastating phases, the Woolfs sensed the growing and imminent danger. They were on the Nazis' death list, and living close to the Sussex coast planned suicide in the event of a German invasion.

The wealth of Virginia Woolf's essays, diaries and criticism defined the critical historical moment in which she lived. Woolf and her circle were deeply involved in literary debates but her diaries, letters and her critical works of the 1930s also reflect on politics and feminism, and are above all fraught with the anxiety of yet another war rising.

In Anglo-American Modernism, apart from Woolf, also the works of T.S. Eliot, Ezra Pound, Amy Levy or James Joyce offer a complex and at times contradictory range of approaches that reflect upon, reify or resist national or religious stereotypes, and more generally, literary Modernism in England significantly engages with representations of Jewishness. In modernist texts, disturbing anti-Semitic stances sometimes coexist with more differentiated and positive depictions of Jewish characters and culture. In some accounts, Jewishness as such is regarded as a defining element of modernism. As Maren Tova Linett suggests: "Jews were often viewed as moderns par excellence. Like modernity itself, they were seen as cosmopolitan, rootless, and urban” (Linett 2007, 80).

Approaches to teaching modernist literature with regard to representations of Jewishness need to be aware of these ambivalences. They need to contextualise their object of study in a dialogue with cultural history, rather than isolate statements and take them as representative of an entire work, or fall into the trap of an intentional fallacy in believing literary works to truthfully represent the stance and opinion of their author. Incongruences such as Woolf's anti-Jewish remarks and her being married to Leonard Woolf cannot and should neither be overlooked nor be explained away. As Linett explains, many modernist writ- 
ers "found in the fictional Jew a floating signifier she could use to define the contours of her literary endeavors” (Linett 2007, 188).

In order to gain insights into the discursive constructions of religion and ethnic belonging identity in modernism, it is necessary that conceptions of 'race' in England during the Victorian era and the early twentieth century be addressed. This also involves looking at the ideological framework of the British Empire, at its colonising policies and political movements such as Irish Home Rule.

Issues of empire and imperial dominance also reveal strategies of constructing the other, in which racial and imperial attitudes often mutually reinforce one another. As Edward Said has shown, 'othering' and ostracising others relies on establishing binaries and constructing the other as a stable, essentialised stereotype (Said 2003, 206). Understanding the ideologies that drive cultural master narratives including those of ethnocentrism as well as teleological and hierarchical interpretations of cultural development also involves looking at newspapers, magazines and popular media in general, in which strategies of placing the other close to savagery, infantilising, or downright de-humanising them can be insidious.

Apart from a thorough knowledge of the historical and cultural realm in which literary texts were written and with which they interacted, for any student or reader of literature, it is vital to analyse the intrinsic and immanent poetic strategies of the texts themselves.

Many of the mechanisms of creating images and narratives of the self and the other are evinced, targeted and undermined by modernist works such as James Joyce's Ulysses (Cheng 1995, 15), sometimes from the oblique angle of allegory or within the dense intertextual network that creates national and religious identities as discursive configurations.

Famously, Ulysses was rejected by the Hogarth Press and prompted Joyce's friend Sylvia Beach to eventually publish the novel with her own press: "Shakespeare and Company” in Paris in 1922. Modelled on Homer's Odyssey, Joyce's novel is set in Dublin on a single day, June 16th, 1904. The Joyce-congregation had later dubbed this day 'Bloomsday', after Joyce's protagonist, the Jewish Leopold Bloom, whose adventures during that day, among a plethora of other things, the novel records. The character of Leopold Bloom caused much controversy. On one occasion, while attending the Dublin symposium on the centennial of Joyce's birth, for instance, Gershom Scholem recalled "a conversation [...] in which David Ben-Gurion said, 'Well, the rabbis might not say that Bloom was a Jew, but I do’” (Epstein 1982, 221).

Jewish literature, religion and culture clearly fascinated Joyce. Hardly any author engaged with Jewish literature and conceptions of Jewishness in quite the way Joyce did. Neil Davison argues that "Jewishness' [...] becom[es] pivotal 
to the representational, narratological, and even historiographical aspects of the novel” (Davison 1996, 1). Part of the reason why Joyce created Leopold Bloom, the convert and peripatetic, marginal figure in a Christian nationalistic culture, as his Ulysses-figure was his interest in the exiled status of the Jewish people and their close family ties which were perhaps the result of it.

At the same time, Joyce portrays the paralysis of Western institutions such as the church, excessive nationalism, sentimental patriotism as well as emotional deprivation and the wilful embrace of a self-deluding stasis. Early on, in his collection of Short Stories Dubliners (1914) he portrayed the petty hypocrisy governing personal relationships along with the pathos of sentimental patriotism in characters that were alienated from social and religious institutions but cannot escape from them.

Joyce had been struggling with his publisher Grant Richards over the publication of Dubliners for seven years, almost as long as it took him to write Ulysses, and during this time, the printer for his Dublin publisher destroyed "the unpatriotic" proofs for the book (Ellmann 1982, 335).

The difficulties Joyce encountered in bringing Dubliners to the public provide a record of late-Victorian prejudice and prudery, with the objections of the various printers and publishers. Joyce, however, albeit being close to despair on several occasions, fought in defence of the placing of every word, and on other occasions he was by no means bashful when he stated his intention to write Dubliners. In his letters we find statements such as: "My intention was to write a chapter of the moral history of my country" or "I have taken the first step towards the spiritual liberation of my country" (Letters II, 134); (Letters I, 62-63). In a letter to Grant Richards, Joyce described the harm his reluctant publisher would cause if he continued to refuse to print Dubliners:

It is not my fault that the odour of ashpits and old weeds and offal hangs round my stories. I seriously believe that you will retard the course of civilisation in Ireland by preventing the Irish people from having one good look at themselves in my nicely polished looking-glass. (Letter to Grant Richards, 23 June, 1906 (Letters I, 63-64))

Joyce's lofty remark about helping along “civilization” and his belief that his stories would liberate the spirits of his countrymen was accompanied by the sentiment that Ireland appeared to him as hostile and stifling to any sort of artistic freedom. Although this cannot be taken as an authorial guarantee to interpret his short stories, he called Dublin the "centre of paralysis" ((Letters II, 134) Grant Richards May 5, 1906).

Joyce, who targeted paralysed institutions, and in A Portrait of the Artist as a Young Man (1916) considers the Irish “a priestridden race” (Joyce 2003 [1916], 37) 
was acutely aware of the growing prejudice and propaganda against Jews on the European continent that also infiltrated Ireland. Wilhelm Marr's pamphlet Der Sieg des Judenthums über das Germanenthum from 1879 was, as Jacob Katz notes, the first "anti-semitic best-seller", and on September 3rd, 1881, the London paper The Atheneum records that "Anti-Semitic literature is very prosperous in Germany".

In both cases, Semitic is conceived as a racial stereotype that relies on the assumption of innate, essentialist characteristics that inform a racial inferiority. During Joyce's lifetime, Jews in many parts of Europe were stereotyped in such ways. They underwent oppression in Russia in the aftermath of Czar Alexander II's assassination in 1881, and German propaganda inundated further parts of Europe. While in Paris, Joyce became familiar with the upheavals around the Dreyfus affair, which had reached one of its crises in September 1902 just before he arrived there (Davison 1996, 61-73).

In England, the Victorian discourse on Jewishness had been influenced by Matthew Arnold's polemics and his schematic observation in Culture and Anarchy where he suggests that Western culture is driven by the contrary yet ideally complementary impulses of the Hebraic (i.e. 'energy driving at practice' with an attendant 'obligation of duty, self-control, and work') and the Hellenic ('the indomitable impulse to know' to see things as the really are...in their essence and beauty') (Davison 1996, $106-111$ ).

Thus, when Stephen Dedalus at the beginning of the novel is urged by Buck Mulligan to be of service to his country and "Hellenise it" $(U 1,6,158)$ this becomes synonymous with the mission to bring cultural and aesthetic superiority to Ireland as opposed to what by some parts of society was perceived as the culturally inferior Hebraic element. Stephen's response is insubordinate and seeks to overcome this dichotomy: "To ourselves ... new paganism ... omphalos" ( $U$ 1, 7, 176).

In the first scene of Ulysses, Buck Mulligan's boisterous incantation “Introibo ad altare Dei" ( $U 1,3,5)$ not only denotes the beginning of the Latin Mass, but also refers to Psalm 43 composed by the Hebrews in Babylonian exile. From the beginning, the themes of occupation and exile are woven into the text with reference to the history of Jewish displacement which is often seen in analogy to the Irish concern for Home Rule (Cheng 1995, 151).

Throughout its eighteen chapters, Ulysses presents a number of characters who voice scathing anti-Jewish sentiments. In the first chapter (Telemachus) the Englishman Haines, whose family had profited from fraudulent colonial trade, and whose name contains the French word for hate 'la haine', proposes a stereotyped nationalist and economic doctrine that draws on the widespread assumption of a Jewish domination of the financial sector: "Of course I'm a Brit- 
isher, Haines's voice said, and I feel as one. I don't want to see my country fall into the hands of German jews either. That's our national problem, I'm afraid, just now" (U 1, 18, 666-668).

Parochial nationalism also pervades the second chapter (Nestor) where the history curriculum at the school in which Stephen Dedalus teaches consists of Roman history and versions of hegemonic histories of imperial power. To Stephen such "History [...] is a nightmare from which I am trying to awake" ( $U$ 2, $28,377)$. His criticism of imperialist practices and beliefs, however, is countered by the sinister headmaster Mr. Deasy, who confronts Stephen Dedalus with his self-righteous and chauvinistic version of Jewish-Irish history: "I just wanted to say, he said. Ireland, they say, has the honour of being the only country which never persecuted the jews. Do you know that? No. And do you know why? [...] Because she never let them in, Mr Deasy said solemnly" ( $U$ 2, 30, 437-442). Mr Deasy's statement is yet another misconstrued view of Jewish history in Ireland, where Jews were expelled in the late thirteenth century and resettled in the 1650s in both England and Ireland under Cromwell. (Davison 1996, 195; Reizbaum 1999, 35-38).

Ulysses is written against these anti-Jewish sentiments that Joyce witnessed on the continent and in Ireland. In 1938 he, for instance, helped Hermann Broch leave Vienna and reach England. During the war, he was himself listed as a Jew by the Swiss Fremdenpolizei when he applied for visas and for permissions to stay in Zurich and when his application was rejected on these grounds to be eventually reconsidered in the light of further evidence. As Richard Ellmann points out: "The subject of the Jews had seized upon Joyce's attention as he began to recognize his place in Europe to be as ambiguous as theirs" (Ellmann 1982, 230).

Yet, Joyce in Ulysses does not only engage in a dialogue with Jewishness in biographical and historical terms. Jewishness rather provides an angle from which to portray and to reflect on contemporary politics and culture. In Ulysses, as I would like to argue, Jewishness becomes both a poetic and a performative stance in which the text presents notions of exile, wandering, hybridity, and otherness in its theme and structure.

To some extent, Leopold Bloom epitomises some characteristics of Joyce's poetic model of Jewishness. As Ben-Gurion is reported to have said, Bloom is not a Jew in the halalic sense of the word. He is a fictional character whose mother was a gentile and he was not circumcised. To a degree, he became familiar with Jewish customs and religious traditions, and yet, time and again, he tried to be part of Irish, and Dublin society in particular. He was baptised a Protestant and then a Catholic. Some critics read him as an Everyman-character, but 
other than Everyman, Bloom verges more towards the Homeric 'Nobody' and remains a marginal figure, a drifter, both an insider and an outsider.

The Dublin of Ulysses that structures Bloom's wanderings is permeated by tokens of imperial ideologies of domination and nationalist rebellion against them. Time and again, his fellow Dubliners make it clear to him that he is not one of them and never will be. When he is attacked by the xenophobic Citizen in the Cyclops-episode, which also represents the myopia of Irish nationalism, he defends himself saying: "Christ was a Jew like me" ( $U$ 12, 280, 1808-1809), only to be attacked even further for his blasphemy. In episodes like these, Bloom exposes the intentional one-sidedness of hegemonic claims to religious, nationalist and cultural superiority.

Leopold Bloom enters the world of Ulysses in the fourth chapter, Calypso, which is set in the home of Leopold and Molly Bloom, where he goes about his domestic routines and can be compared to Odysseus who is held in thrall by the nymph Calypso on her enchanted island. As opposed to Stephen Dedalus, who contemplates the ineluctable modalities of the visible and the signatures of all things in the preceding Proteus-chapter, Jeri Johnson calls Calypso "a bodied text [-] a corpus" (Joyce 1998 [1922], 793). And indeed, the chapter begins and ends with descriptions of somatic processes, and is interspersed with moments in which the characters both conceal and reveal their physical needs. Molly, like Calypso the concealer, hides a letter from her lover Blazes Boylan, and Bloom likewise more or less secretly indulges in fantasies about other women.

The processes of incorporation and metabolic exchange are treated in highly ambivalent ways that invoke a number of discourses on Jewishness. The chapter starts with the sentence: "Mr Leopold Bloom ate with relish the inner organs of beasts and fowls" ( $U$ 4, 45, 1-2). He decides to go on his first errand and buy a pork kidney for breakfast at Dlugacz, a polish-Jewish butcher. Similar to the processes of filtration and absorption accomplished by the human kidney, Bloom becomes a hybrid somatic entity. He absorbs some parts alluding to his Jewish identity, rejects others, and transforms them into new combinations: "Kidneys were in his mind" $(U 4,45,6)$ as he serves milk to his cat.

This entirely unkosher constellation of food is even further elaborated on when Bloom enters the butcher's shop and inhales the smell of blood: "[he] breathed in tranquilly the lukewarm breath of cooked spicy pigs' blood" ( $U$ 4, 48, 143-144). Sensual impressions guide Bloom's meandering thoughts in a way in which he transports images from one context into another and synthesises, even conflates them. He finally sees the object of his desire, the kidney, and is enthralled by it: "A kidney oozed bloodgouts on the willowpatterned dish: the last" $(U 4,48,145)$. The sight of the different meats on display leads his thoughts to wander further and from there to contemplate the body of a female customer 
in unorthodox ways. He wonders whether he should follow her: "To catch up and walk behind her if she went slowly, behind her moving hams. Pleasant to see first thing in the morning" ( $U$ 4, 49, 171-173). Bloom's craving for pork and his erotic appetites merge until the former prevails and Bloom decides to return home.

Bloom remains an observer who is interested in the materiality of words and things. He contemplates the Eucharist: "Corpus: body. Corpse. Good idea the Latin. [...] They don't seem to chew it: only swallow it down. Rum idea: eating bits of a corpse. Why the cannibals cotton to it. [...] Something like those mazzoth: it's that sort of bread: unleavened shewbread. Look at them. Now I bet it makes them feel happy" ( $U$ 5, 66, 350-359). His empirical, non-judgmental view makes it possible to relate the incongruous as he recognises cultural similarities between Christians, cannibals, and Jews.

Jewishness furthermore becomes a discursive framework in which images of the body and of land become mutually pervasive. The notion of the body, particularly the female body, for Bloom, is tied to the notion of space and place. On his way home, he passes an advertisement for a Zionist colony by the Agendath Netaim, the "company of planters", to develop land for prospective settlers, and his imagination wanders to erotically charged images of orange groves and melon fields.

Analogous to bodily processes of exchange and transformation that are carried out by the kidney as the organ the chapter consistently returns to, Bloom ponders the dynamics of financial exchange: "You pay eighty marks and they plant a dunam of land for you [...]. Every year you get a sending of the crop. Your name entered for life as owner in the book of the union. [...] Bleibtreustrasse 34, Berlin, W 15" (U 4, 49, 194-199).

The lure that homecoming presents to the exile and the appeal of possessing, of owning a piece of land for life, is, however, linked to a moral obligation: to remain true. "Bleibtreustrasse” alludes to Molly's and Bloom's infidelity in religious, cultural and sexual terms, which not only render them outcasts from the eternal homeland envisioned by the Zionist project, but also from the mythological Ithaca with Molly conforming not exactly to the model of the chaste Penelope.

Bloom associates fruitfulness and fecundity with his wife Molly when he thinks about olives and relates oranges and citrons to both Jaffa and Gibraltar ( $U$ 4, 49, 211), the place where Molly was born. However, similarly to the loss of his homeland, he realises that he will never exclusively or entirely possess Molly. The chain of associations about fertile arable land released by his contemplation of Molly, however, is abruptly contrasted by the sight of an old woman carrying a wine bottle, which leads him to think about barrenness, and old 
age: "The oldest people. Wandered far away over all the earth, captivity to captivity, multiplying, dying, being born everywhere. It lay there now. Now it could bear no more. Dead" ( $U$ 4, 50, 225-227). Horrified at his vision, he resumes his senses and hurries home to "[b]e near her ample bedwarmed flesh. Yes, yes" ( $U$ 4, 50, 238-239) - anticipating Molly's final yesses that will conclude the novel (Olk 2013, 333).

In Bloom's imagination his home-land and his wife become a point of departure and return. Both, however, have become highly ambivalent and offer no stable epistemological ground to find comfort on. Rather the notion of home and the Homeland itself becomes an imaginary utopia, a no-place that challenges nationalist ideas of origin and teleological models of history. Hence at the end of this passage, Bloom realises the loss of land, the partial loss of his wife, and above all the loss of Rudy, his son, which makes it impossible for Bloom to continue any patrilineal aspirations.

Next to 'Calypso', the chapter that most explicitly deals with multiple perspectives on Jewishness, is 'Circe', another female enchantress living on an island. Role-play, concealing and revealing of diverse identities are at play in the Circe-chapter of Ulysses that is set in the Dublin underworld. In Circe, the novel itself undergoes a change of generic identity and becomes a play. The chapter, part theatre part courtroom, consists of carnivalesque as well as nightmarish scenes in which Bloom undergoes a number of trials and is confronted with the psychopathologies of his past. Figures from his past such as his father Rudolph appear in the fashion of Hamlet's father's ghost to chide him "not [to] go with drunken goy ever" ( $U 15,357,253-254)$ and reprimand him for his guilt of apostasy in a paraphrase of Genesis 12:1: “Are you not my son Leopold, the grandson of Leopold? Are you not my dear son Leopold who left the house of his father and left the god of his fathers Abraham and Jacob?” ( $U$ 15, 357, $260-262)$

The chapter also recapitulates the more immediate past of the novel when e.g. the polish-Hungarian butcher Moses Dlugacz appears as a mock allegory of Justitia, "holding in each hand an orange citron and a pork kidney" ( $U$ 15, 379, 988-989) and announces: "Bleibtreustrasse, Berlin, W. 13” (U 15, 379, 991).

From rituals of punishment and scapegoating, Bloom emerges as a Messianic figure, who announces the coming of a new era: "I, Bloom, tell you verily [...] ye shall ere long enter into the golden city which is to be, the new Bloomusalem in the Nova Hibernia of the future" ( $U$ 15, 395, 1542-1545). The motif of the Promised Land here includes both Israel and Ireland, "green Erin, the promised land of our common ancestors" ( $U$ 15, 394, 1517-1518), and points to both the Irish and the Jews struggling for their homeland. 
Bloom pronounces his aims and ambitions as leader of this "[n]ew worlds for old” in a mock-biblical, prophetic style:

\begin{abstract}
Union of all, jew, moslem and gentile. Three acres and a cow for all children of nature. Saloon motor hearses. Compulsory manual labour for all. [...] Electric dishscrubbers. Tuberculosis, lunacy, war and mendicancy must now cease. [...] weekly carnival with masked licence, bonuses for all, esperanto the universal language with universal brotherhood. No more patriotism of barspongers and dropsical impostors. Free money, free rent, free love and a free lay church in a free lay state. [...] Mixed races and mixed marriage ( $U$ 15, 399-400, 1686-1699).
\end{abstract}

Bloom's bold parodic vision of a free, Esperanto-speaking universal interfaith brotherhood that indulges in the amenities of modern life responds to patriotism as well as exclusive notions of race, religion and marriage. Once again, his promotion of motored hearses, electric dish-scrubbers and the end of tuberculosis reveal his interest in everyday life as well as a practical and unsentimental attitude to the benefits of modern machinery and medicine.

After the chapter fantastically stages the second coming (and going) of Elija, Bloom and Stephen eventually get together: “Woman's reason. Jewgreek is greekjew. Extremes meet” ( $U$ 15, 411, 2097-2098). Derrida in Writing and Difference, comments on Ulysses: "Are we Jews? Are we Greeks? We live in the difference between the Jew and the Greek, which is perhaps the unity of what is called history [...] What is the legitimacy, what is the meaning of [...] [Joyce's] proposition [...] 'Jewgreek is Greekjew. Extremes meet?”' (Derrida 1978 [1967], 151).

Derrida is referring to the Arnoldian division of modern Western civilisation, and on the surface, Stephen Dedalus and Leopold Bloom could be seen as manifestations of both principles: Greek metaphysics represented by the Aristotelian Stephen, and Biblical Messianism represented by the prophetic Bloom. In Derrida's view, both cultures have remained dualistically opposed in Western history to the extent that they offered rival 'logocentric' systems. In the Circe-chapter, however, Bloom and Stephen also assume character attributes of one another. Bloom, after having met Stephen, becomes more rational and self-contained whereas Stephen acts increasingly unreasonable and impulsively destroys a chandelier. The chiastic constellation is further complemented by the idea that Bloom the Hebraic father has reunited with Stephen the (lost) Hellenic son.

Ulysses, in the character of Leopold Bloom, throughout the novel rehearses topoi and discourses related to ideas of Jewishness. He contemplates their practical as well as somatic effects, interacts with stereotypical conceptions, and undergoes many conversions himself. Bloom, his physical wanderings, his transformative imagination and the performative bodily transformations that he undergoes, figure a kind of Jewishness in which opposites are no longer dualisti- 
cally opposed, as in the paternal code, but are subversively played off against one another until the opposition is undone. In this vein, the novel also presents Molly Bloom as a third element between the extremes. Notwithstanding the many ambivalences that govern the representation of Jewish characters and the engagement with Jewishness in Modernist fiction, in major works such as Ulysses, the negotiation of multiple perspectives leads to new imaginative syntheses that configure Jewishness as a product and effect of the text.

\section{Bibliography}

Cheng, Vincent J. James Joyce, Race, and Empire. Cambridge: Cambridge University Press, 1995.

Davison, Neil R. James Joyce, Ulysses and the Construction of Jewish Identity. Cambridge: Cambridge University Press, 1996.

Derrida, Jacques. Writing and Difference. Trans. Alan Bass. Chicago: The University of Chicago Press, 1978.

Ellmann, Richard. James Joyce. Oxford: Oxford University Press, 1982.

Epstein, Edmund L. "Joyce and Judaism.” The Seventh of Joyce. Ed. Bernard Benstock. Harvester: Indiana University Press, 1982. 221-224.

Letters of James Joyce. Vol. I. Ed. Stuart Gilbert. New York: Viking Press, 1957; reissued with corrections (1966); vols. II and III. Ed. Richard Ellmann. New York: Viking Press, 1966.

Gillespie, Diane F. "Publishing on the Brink of World War II: The Woolfs, the Hogarth Press and The Refugees." South Carolina Review 48.2 (2016): 14-30.

Joyce, James. Dubliners. Ed. Terence Brown. London: Penguin, 1992.

Joyce, James. A Portrait of the Artist as a Young Man. Ed. Seamus Deane. London: Penguin, 2003.

Joyce, James. Ulysses. Ed. Jeri Johnson. Oxford: Oxford University Press, 1998.

Joyce, James. Ulysses. Ed. Hans Walter Gabler. London: Bodley Head, 1986.

Linett, Maren Tova. Modernism, Feminism and Jewishness. Cambridge: Cambridge University Press, 2007.

Nadel, Ira. Joyce and the Jews: Culture and Texts. Houndmills: Palgrave Macmillan, 1989.

Olk, Claudia. "Why say Yes in Joyce? Molly Bloom's Yes Because in the 'Penelope'-Episode of Ulysses”. Interfaces of Morphology: A Festschrift for Susan Olsen. Ed. Holden Härtl. Berlin: Akademie, 2013. 323-334.

Said, Edward W. Orientalism. London: Penguin, 2003.

Simpson, Kathryn. Woolf. A Guide for the Perplexed. London: Bloomsbury Publishing, 2016. Reizbaum, Marilyn. James Joyce's Judaic Other. Stanford: Stanford University Press, 1999.

Woolf, Leonard. Downhill All the Way: An Autobiography of the Years 1919-1939. New York: Harcourt Brace Jovanovich, 1967.

Woolf, Virginia. Three Guineas. Ed. Naomi Black. London: Shakespeare Head, 2001.

Woolf, Virginia. The Diary of Virginia Woolf IV. Ed. Anne Olivier Bell, and Andrew McNeillie. London: The Hogarth Press, 1982. 
